\title{
Fashioning the Materiality of the Pilgrimage: The hajj Travelogue of Muḥammad Labīb al-Batanūnī
}

\author{
Ammeke Kateman \\ Department of History, European Studies and Religious Studies, \\ University of Amsterdam, The Netherlands \\ ammekekateman@hotmail.com
}

\begin{abstract}
In 1911, the Egyptian travel writer Muhammad Labīb al-Batanūnī published a highly informative account of his pilgrimage journey, al-Rihla al-Hijäzizya. This article is interested in al-Batanūnì's representation (or fashioning) of the hajj and its materiality, as it reflects the conventions of his time and with which the author simultaneously hopes to shape the interpretations and practices of his contemporaries. Specifically, the article focuses on the way al-Batanūnī represents the objects and matters of the hajj (for example, Zemzem water) in opposition to interpretations and practices of his contemporaries within, as well as beyond, Islam.
\end{abstract}

\section{Keywords}

ḥajj - pilgrimage - Muḥammad Labīb al-Batanūnī - travel literature - hajj travelogue - Islamic reformism - Salafiyya - materiality

In 1911, the Egyptian travel writer Muhammad Labīb al-Batanūnī (d. 1357/1938) published an elaborate account of his journey to and in the Hijāz, al-Rihla al-Hijäzioyya (The Hijāz journey). ${ }^{1}$ This widely read and oft-referenced account relates the hajj of the year 1327h (December 1909), which he experienced and documented as an official travel writer in the entourage of the Egyptian

1 Muhammad Labīb al-Batanūnī, al-Rị̣la al-Hịjāziyya (Cairo: Maktabat al-Thaqāfa al-Dīniyya, n.d. $[1329 / 1911])$. 
khedive 'Abbās Hilmī II. The travelogue is heavy in its information load, containing elaborate descriptions of the history and contemporary social, urban, and sacred geographies of the places they visited, in addition to accounts of the hajj rituals and places and objects connected to the hajj. ${ }^{2}$ It intersperses these passages with day-by-day entries on the journey al-Batanūnī, the khedive, and the rest of their travel group made - the places they visited, the people they met, with at times strikingly emotional descriptions of their feelings and sensations when praying at the Ka'ba or seeing the initial contours of Medina. Furthermore, it contains photos (often reprints), maps (both new and reprints), and tables. ${ }^{3}$

al-Batanūnīs travelogue to the Hijāz is a hybrid text, combining several genres and serving multiple purposes. This is not uncommon for an ArabicMuslim hajj travelogue. It is also not uncommon for the genre of travelogues to mix several types of text. As a body of writing, therefore, travel literature seems most precisely defined by sharing "travel as an essential condition for its production" and is sometimes referred to as the "genre of genres".

Perhaps because of this characteristic, travelogues - and this hajj account by al-Batanūnī, too - lend themselves to many forms of analysis. ${ }^{5}$ Handled

2 Hava Lazarus-Yafeh analysed al-Batanūnī's description of the Ka'ba and the Black Stone: Hava Lazarus-Yafeh, "Modern Muslim Attitudes towards the Ka'ba and the Hadjdj:The Rise of NeoFundamentalism in Islam", in Some Religious Aspects of Islam: A Collection of Articles (Leiden: Brill, 1981), 121-22.

3 For its maps and images, it draws primarily on the (collected) hajj travelogues of the Egyptian general Muḥammad Ṣādiq Bāshā, Dalīl al-hajj li-l-wārid ilā Makka wa-l-Madīna min kull fajj (Būlāq: al-Mațbaca al-Kubrā al-Amīrīya, 1313/1896).

4 Joan-Pau Rubiés and Francis Bacon, "Travel Writing as a Genre: Facts, Fictions and the Invention of a Scientific Discourse in Early Modern Europe", Journeys. International Journal of Travel and Travel Writing 1 (200o), 6 quoted in: Laila Hashem Abdel-Rahman El-Sayed, "Discourses on Emotions: Communities, Styles, and Selves in Early Modern Mediterranean Travel Books: Three Case Studies" (PhD Dissertation, University of Kent and Freie Universität Berlin, 2016), 32, <https://kar.kent.ac.uk/56635/>. For a discussion of the genre of Middle Eastern travelogues, see Venturing Beyond Borders: Reflections on Genre, Function and Boundaries in Middle Eastern Travel Writing, ed. Bekim Agai, Olcay Akyıldız, and Caspar Hillebrand (Würzburg: Ergon, 2013), part 3 ("Drawing Lines: Borders and Crossings in Genre").

5 The following discussion of the study of travel literature, mostly pertaining to Arabic and Middle Eastern travel literature, is based on: Richard Van Leeuwen, "Autobiography, Travelogue and Identity", in Writing the Self. Autobiographical Writing in Modern Arabic Literature, ed. Robin Ostle, Ed de Moor, and Stefan Wild (London: Saqi Books, 1998), 27-29; Billie Melman, "The Middle East / Arabia: "The Cradle of Islam," in The Cambridge Companion to Travel Writing, ed. Peter Hulme and Tim Youngs (Cambridge: Cambridge University Press, 2006), 105-21; Stephan Conermann, "Reiseberichte als Erzähltexte", in "Wenn einer eine Reise tut, hat erwas zu erzählen”: Präfiguration-Konfiguration-Refiguration in muslimischen Reiseberichten, ed. Bekim Agai and Stephan Conermann (Berlin: EB-Verlag, 2013), 7-27; Venturing Beyond Borders, ed. Agai et al.; El-Sayed, "Discourses on Emotions", chap. 1. 
with care, travelogues might be used in a more positivist way, for their information about the "objects" they describe - the landscapes, peoples, events, and histories they document. For example, historians used al-Batanūn's observations on the quarantine facilities and camp arrangements in Minā to describe the twentieth-century history of the hajj. ${ }^{6}$ Others referred to al-Batanūnī's expositions of the history of Mecca to provide insight into the earlier history of the hajj. ${ }^{7}$

For quite some decades now, travelogues - and hajj travelogues, too - have also been analysed for their subjective making of self, other, and place, and for their fictional and literary quality. ${ }^{8}$ For example, several hajj travelogues have been analysed not for their information about the organisation of the hajj or the Hijāz in a particular time, but for the autobiographical ways in which the author construes a specific public image of himself that matches contemporaneous social conventions. ${ }^{9}$ In addition, focusing especially on twentieth-cen-

6 Sylvia Chiffoleau used al-Batanūnīs travelogue as a source (amongst other types of sources) to describe the early twentieth-century quarantine facilities for hajj pilgrims at al-Ṭurr in the Sinai Peninsula, the libraries and bookshops in Mecca, and the lay-out of the camp at Minā: Sylvia Chiffoleau, Le Voyage à La Mecque (Paris: Belin, 2015), 189-98, 296, 304, 350 (n.32). Similarly, one might think of Rita Stratkötter's use of Ibrāhīm Rif'at Bāshā's travelogue to write a socio-economic history of the hajj, in which she also refers to al-Batanūnīs travelogue in her description of quarantine: Rita Stratkötter, Von Kairo nach Mekka: Sozial- und Wirtschaftsgeschichte der Pilgerfahrt nach den Berichten des Ibrähïm Rif'at Bāšā: Mirāt al-Haramain (Berlin: Klaus Schwarz, 1991), 103. Interestingly, it is unclear if al-Batanūnī actually witnessed the quarantine facilities at al-Ṭūr at first hand, as the khedive and his party took the northern route (through the port of Haifa) home. Such an observation might act as a reminder to treat this type of source with care when writing a history of the hajj.

7 For example, Saud al-Sarhan used al-Batanūnī's travelogue to describe the nineteenthcentury history of the hajj: Saud al-Sarhan, "The Saudis as Managers of the Hajj", in The Hajj. Pilgrimage in Islam, ed. Eric Tagliacozzo and Shawkat M. Toorawa (New York: Cambridge University Press, 2016), 196-212. Because al-Batanūnī was employed by the khedive himself, the information in al-Batanūni's political history of Mecca in the nineteenth century - especially considering the special role Egypt and the khedive's ancestor Muhammad 'Alī had in this history - should quite obviously be handled with care in order to render it useful.

8 One might think of numerous case studies for Middle Eastern and Arabic travel literature: Venturing Beyond Borders, ed. Agai et al., part 2 ("Writing on Self and Other"); Writing the Self. Autobiographical Writing in Modern Arabic Literature, ed. Robin Ostle, Ed de Moor, and Stefan Wild (London: Saqi Books, 1998), part 1 ("Voyages of Self-Definition").

9 See, e.g., the following analyses of hajj travelogues: Rainer Brunner, "The Pilgrim's Tale as a Means of Self-Promotion: Muhammad Rashīd Riḍās Journey to the Hijāz (1916)", in The Piety of Learning. Islamic Studies in Honor of Stefan Reichmuth, ed. Michael Kemper and Ralf Elger (Leiden: Brill, 2017), 270-91; Siobhan Lambert-Hurley, "An Introduction to Nawab Sikander Begum's Account of Hajj", in A Princess's Pilgrimage: Nawab Sikandar Begum's “A Pilgrimage to Mecca" (Indiana University Press, 2008), 10-13. One might also think of Homayra Ziad's analysis of the way the hajj travelogue of 'Abd al-Majid Daryabadi is 
tury South Asian hajj accounts, Barbara Metcalf has argued that travelogues' particular representations of the hajj may give access to the "changing patterns of religious sensibilities in a world in technological, social and political transition". 10

This article does not use al-Batanūnī's travelogue to write a history of the hajj in the year 1909, nor does it primarily analyse the ways in which al-Batanūnī builds up a certain image of himself or his patron (the Egyptian khedive). ${ }^{11}$ Instead, it focuses on the text itself and al-Batanūnī's particular and time-bound representation (or fashioning) of the hajj and its elements for his contemporaries - within and beyond Islam. Besides analysing the general approach of the author, this article specifically examines cases concerning what I have called the materiality of the hajj, by which I mean physical objects and other types of matter (such as water) related to the hajj rituals, as well as the discussions on the relation between the material and the immaterial or spiritual.

More specifically, it examines the manner in which al-Batanūni fashions the hajj and its materiality in order to suit and reflect several of the global discursive conventions of his time. The verb "fashioning", loosely borrowing an oft-repurposed term that Stephen Greenblatt uses for authors' conscious construction of the self in English Renaissance literature, is used in this article to emphasise the "contemporaneity" of al-Batanūni’s representation of the hajj and its materiality, notwithstanding the equally real "continuity" in the ritual and in the genre. ${ }^{12}$ The term is also used in an additional, yet interconnected

utilised to created "a Mecca-focused communal identity among Indian Muslims". Homayra Ziad, "The Return of Gog: Politics and Pan-Islamism in the Hajj Travelogue of 'Abd al-Majid Daryabadi", in Global Muslims in the Age of Steam and Print, ed. James L. Gelvin and Nile Green (Berkeley: University of California Press, 2014), 231.

Barbara Metcalf, "The Pilgrimage Remembered: South Asian Accounts of the Hajj", in Muslim Travellers: Pilgrimage, Migration, and the Religious Imagination, ed. Dale F. Eickelman and James Piscatori (London: Routledge, 1990), 86. For more general notes on the way that any narrative representation of reality is like a "knot" in which contemporary discourses and conventions come together and become entangled, see Conermann, "Reiseberichte als Erzähltexte", 13. See also Nünning on the "prefiguration" on which travelogues inevitably draw: Ansgar Nünning, "Zur mehrfachen Präfiguration/Prämediation der Wirklichkeitsdarstellung im Reisebericht: Grundzüge einer narratologischen Theorie, Typologie und Poetik der Reiseliteratur", in Points of Arrival: Travels in Time, Space, and Self-Zielpunkte: Unterwegs in Zeit, Raum und Selbst, ed. Marion Gymnich et al. (Tübingen: Francke, 2008), 13 .

11 See below, notes 17 and 48, for some observations on the ways in which al-Batanūnìs travelogue builds a specific public persona of the khedive.

12 Stephen Greenblatt, Renaissance Self-Fashioning: From More to Shakespeare (Chicago: University of Chicago Press, 1980), 2. Rainer Brunner explicitly mentions "contemporaneity" in the introduction to his analysis of the hajj travelogue of Rashīd Riḍa, besides it being a "timeless" experience: Brunner, "Pilgrim's Tale as a Means of Self-Promotion", 270. 
way. al-Batanūnī also implicitly and explicitly situates his representation of the hajj vis-à-vis those of his Muslim and non-Muslim contemporaries - contesting and rejecting their interpretations, beliefs, and practices, as well as aiming to change them. Indeed, with his particular interpretation of the hajj in his travelogue, he intends to re-form the hajj interpretations of his time. Thus, this article studies two separate, albeit strongly connected aspects of al-Batanūnīs fashioning of the hajj and its materiality: both his in-text and time-bound representation of the hajj, as well as the efforts his text entails to shape the interpretations of his contemporaries.

\section{Presenting the Simple Facts of the hajj}

In his narratological analysis of travelogues and travel literature in relation to the reality they (claim to) represent, literary scholar Ansgar Nünning first calls attention to what he calls the "configuration" of the travel text itself - the selection, combination, relation, and communication of elements into a narrative in travelogues. ${ }^{13}$ By highlighting this act of configuration, Nünning implies that there is nothing self-evident about what elements are narrated, in what order, or in what manner. Instead, these choices should be the object of analysis (amongst other aspects).

al-Batanūnì's account of the hajj is lengthy and contains various elements. The following section first intends to give an impression of his selection, combination, and communication of elements for representing the hajj in his travelogue, and how to interpret his specific style of representation in this particular period.

After his introduction on the background and reasons behind his travelogue, al-Batanūnī begins with an account of the history of the Arab "nation" or

For some analyses that also deal with the "contemporaneity" of modern Muslim hajj travelogues, besides those mentioned in the previous footnotes, see F.E. Peters, The Hajj : The Muslim Pilgrimage to Mecca and the Holy Places (Princeton: Princeton University Press, 1994); Richard Van Leeuwen, "Islamic Reform and Pilgrimage: The Hajj of Rashid Rida in 1916", in Hajj. Global Interactions through Pilgrimage, ed. Luitgard Mols and Marjo Buitelaar (Leiden: Sidestone Press, 2015), 83-93. On the contemporaneity of hajj travelogue photographs, see Stephen Sheehi, The Arab Imago: A Social History of Portrait Photography, 1860-1910 (Princeton University Press, 2016), chap. 8.

13 Nünning, "Wirklichkeitsdarstellung im Reisebericht", 14. See also Ansgar Nünning, "Making Events - Making Stories - Making Worlds: Ways of Worldmaking from a Narratological Point of View", in Cultural Ways of Worldmaking: Media and Narratives, ed. Vera Nünning, Ansgar Nünning, and Birgit Neumann (Berlin/New York: de Gruyter, 2010), 191-214. 
"community" (umma; pp. 13-43) $)^{14}$ and a geographical and ethnographic description of the Arabian Peninsula (pp. 44-64). The text then switches to an account of the train and sea journey of the khedive from Egypt to Jedda (pp. 6569 ), followed by the urban geography of Jedda and its surroundings (pp. 7080 ). After relating the khedive's arrival and stay in Jedda, al-Batanūni continues with the khedive's journey to Mecca (pp. 81-87) and his first days there (pp. 87105), narrating their feelings and sensations of seeing the Kaba for the first time and providing information about the Islamic historical buildings and tombs in or near Mecca that the khedive visited. After an intermezzo on the road conditions from Egypt to the Hijāz before and after the introduction of steam transportation (pp. 105-13), al-Batanūnì discusses the infrastructure, climate, and people of the city of Mecca (pp. 113-41) and the city's history (pp. 14151). He proceeds to the architecture and functionaries of the Holy Mosque (pp. 152-61) and the Kaba, the area around it, its sacred history, and the rituals related to it (pp. 162-203). The next section describes and explains the hajj, including an explicitly prescriptive section on "How to do the hajj, o Muslim" and a discussion of the ritual garment (ihrām; pp. 203-27). Thereafter, al-Batanūnī turns to the continuation of the hajj outside of Mecca, both the rituals and the places of 'Arafât, Muzdalifa, and Minā (pp. 227-47), and documents the khedive's visits and meetings there (pp. 247-66). Next station of the text is the journey to Medina (pp. 267-81) and the khedive's travels to Medina in particular, including his party's highly emotional and sensational experience of seeing the Prophet's city for the first time and his prayer in the rawda near the Prophet's tomb (pp. 281-311). al-Batanūnī goes on to describe the sacred area (haram) of Medina, architecturally and historically (pp. 312-39) and proceeds to the infrastructure and the traits of the people of Medina (pp. 339-54). The last section of the travelogue concerns the various routes from Medina to Egypt (pp. 354-65), including the quarantine facilities at al-Tür, and the khedive's journey back to Egypt via the northern route through Damascus (pp. 366-88). The book ends with the endorsements the book received prior to publishing, and an index.

As he announces in his introduction, al-Batanūnī conveys not only the theological or juridical aspects of the hajj but also its urban, societal, geographical,

14 On the changing and diverse meanings of umma in the nineteenth century, see Helga Rebhan, Geschichte und Funktion einiger politischer Termini im Arabischen des 19.Jahrhunderts, 1798-1882 (Wiesbaden: Harrassowitz, 1986), 24-28; Ami Ayalon, Language and Change in the Arab Middle East: The Evolution of Modern Political Discourse (New York: Oxford University Press, 1987), 27-28; Florian Zemmin, "Modernity without Society? Observations on the term mujtama' in the Islamic Journal al-Manār (Cairo, 1898-1940)", WI 56:2 (2016), 223-47, <https://doi.org/10.1163/157006o7-00562po4>. 
and historical dimensions, in addition to recounting the travel experiences of the khedive. His travelogue provides many pages full of descriptions and explanations on all these aspects, informing his readers factually - both qualitatively and quantitatively - about the succession of rulers in Mecca, Islam's sacred history concerning the Kaba, the formulae to utter during the various rituals, the number of schools and presses in Mecca, and the etymology and current employment of quarantine, amongst many other facets. Thus, he writes in his introduction, he sets out to unveil "the facts" (haqiqa) about the hajj, and hopes to be of service to both science and Islam. ${ }^{15}$

Most of the travelogue's sections radiate a scientific factuality and objectivity. This impression of veracity is reinforced by the regularly provided maps and tables that visualise or categorise the information of the main text, such as a table of the different elements of the hajj by the four Sunni madhāhib, a map and table of the various Arab tribes and their locations and numbers, or layouts of the tent camp at Minā or the house of Khadija. In addition, the travelogue contains photos of the holy places, which also suggest immediate and unmediated access to the reality there. ${ }^{16}$ Furthermore, as has been said, alBatanūnī alternates these informative sections with his day-by-day documentation of the khedive's official journey, as a first-hand (and therefore seemingly truthful) account of an eyewitness. ${ }^{17}$ His travelogue, in this sense, is written not just as any personal account of his hajj, but represents an account of the hajj written by al-Batanūnī as an official and scientific-minded "travel writer" (the profession under which the Egyptian journal al-Manār introduces him in its review), expected to provide objective historical, literary, and agricultural scientific knowledge and reliable, professional first-hand observations. ${ }^{18}$

15 al-Batanūnī, al-Riḥla al-Hijāziyya, 11-12.

16 This strong suggestion of truthfulness is dependent upon the so-called indexicality of the representation (the physical relation between object and image; in the case of photography, this relates to the chemical conversion of the light that is reflected off the photographed object through which the image is created) and the so-called iconicity of the photo (the accuracy and similarity of the representation, i.e. the degree to which the image actually looks like the photographed object). See Piotr Sadowski, "The Iconic Indexicality of Photography", in Semblance and Signification, ed. Pascal Michelucci, Olga Fischer, and Christina Ljungberg (Amsterdam: John Benjamins Publishing Company, 2011), $353-68$.

This impression of veracity of travelogues as eyewitness accounts has been described numerous times, for example in Conermann, "Reiseberichte als Erzähltexte". Yet, despite this suggestion of veracity and reality, one might also point to the way al-Batanūnī represents the khedive. For example, he describes the official receptions the khedive was thrown, but also the merciful rain that miraculously appeared after the khedive had entered the mosque in Mecca: al-Batanūnī, al-Rịhla al-Hijäziyya, 93, 95. 
al-Batanūnīs professional travelogue was not unique in his emphasis on facts and science at that time. ${ }^{19} \mathrm{He}$ explicitly writes that for distances he draws upon the equally factual hajj accounts of the Egyptian hajj commander Muhammad Ṣādiq Bāshā from the 1870 os and 188os, born out of a military survey of the Hijâz and the route to and from Egypt, from whom he also copies some maps. ${ }^{20}$ His claim to objective factuality, furthermore, matches the informative style of the travelogues he himself had already written (to Europe, 19o1) or would still write (to Andalusia, 1928, and the United States, 1930). Finally, it is this factuality that is assessed by his contemporaries, as a later hajj writer takes care to fully quote a deceased Meccan scholar's list of fourteen corrections to al-Batanūni's descriptions of Mecca (such as al-Batanūnī's miscount of the number of citadels, minarets, or presses, and his mistakes in the order of the Hanafĩ prayer or the opening times of the Kaba for men and women)..21

In his presentation of hajj facts, al-Batanūnī freely merges elements from Islam's sacred history (about Ibrāhim or the time of the Prophet Muhammad) with an ethnographic discussion of peoples' customs, or juxtaposes ritual prescriptions with insights from chemistry and human religious history. He refers to haditths as well as to contemporaneous scientists, apparently using them as authorities of equal weight. Clearly, al-Batanūnì considers both types of knowledge vital in his presentation of the truth about the hajj and sees no contradiction between the facts of Islam and those of secular knowledge at that time. Moreover, by combining the two and merging them seamlessly, he demonstrates - or rather, performs - their compatibility, both implicitly and explicitly. For example, the ị̂ām for al-Batanūnì is not only a ritual requirement in Islam but also happens to be beneficial for the physical body as it exposes it to air, in the same manner as contemporaneous health spas in the European mountains or at the coast do. In such ways, he presents the hajj and contemporary knowledge norms in sync with each other. In this respect, al-Batanūnī's travelogue matches the high appreciation of science within the oft-overlapping late

biographical dictionary of Arabic and orientalist littérateurs, al-Ziriklī describes al-Batanūnī as working in literature $(a d a b)$ and history $(t \bar{a} r \bar{k} k h)$, listing the various travelogues al-Batanūnī wrote: Khayr al-Dīn al-Ziriklī, "al-Batanūnī", in al-Átām. Qāmūs tarājim liashhar al-rijäl wa-l-nisä’ min al-'arab wa-l-musta'ribīn wa-l-mustashriqīn, 8 vols. (Beirut: Dār al-'Ilm li-l-Malāyīn, 2002), vol. 7, 123-27.

19 This article mainly situates al-Batanūnīs travelogue in his own time, but one might also compare his factual style to that of earlier Arab geographers and travel writers.

20 al-Batanūnī, al-Rihla al-Hijāziyya, 12. For the compilation of Muhammad Ṣādiq Bāshā’s travel accounts: al-Liwā̄ Muhammad Ṣādiq Bāshā, al-Riḥalāt al-Hịjāziyya, ed. Muḥammad Humām Fikrī (Beirut: Badr li-l-Nashr wa-l-Tawzī‘, 1999).

$21 \quad$ Khayr al-Dīn al-Ziriklī, Mã ra'ayt wa-mā samát min Dimashq ilā Makka (1929), ed. Mufìd Najm (Abu Dhabi: Dār al-Suwaydī li-l-Nashr wa-l-Tawzī‘, 2009), 123-27. 
nineteenth- and early twentieth-century Arabic nahda circles, as well as Islamic reformist milieus, in which the compatibility of science and religion and the continuing relevance of religion were argued and reiterated. ${ }^{22}$

At the very beginning of his book, furthermore, it becomes clear that alBatanūnī contrasts his facts with the misunderstandings and errors of others in interpreting and presenting the hajj. He announces that his account will bring about the truth (haqiqa) about the hajj, clearly differentiated from bias and error (gharad). ${ }^{23}$ This raises the expectation that he is categorically clear and unambiguous in assessing at least certain aspects of the hajj as correct or incorrect. ${ }^{24}$ His introduction also makes clear that his "facts" are intended to mend the errors of his contemporaries. In order to improve people's dire knowledge, he writes that he exposes the rituals in a simple and easy expression, instead of the overly detailed existing descriptions of the hajj. ${ }^{25}$

22 On the importance of "science" in nahda- and Islamic reformism circles, see, e.g., the following works (with references to the concept of science and knowledge throughout): Albert Hourani, Arabic Thought in the Liberal Age, 1798-1939, 2nd ed. (1962; repr., Cambridge: Cambridge University Press, 1983); Stephen Sheehi, Foundations of Modern Arab Identity (Gainesville: University Press of Florida, 2004); Marwa Elshakry, Reading Darwin in Arabic, 1860-1950 (Chicago: University of Chicago Press, 2013); Dyala Hamzah, ed., The Making of the Arab Intellectual: Empire, Public Sphere and the Colonial Coordinates of Selfhood (Milton Park: Routledge, 2013); Abdulrazzak Patel, Arab Nahdah: The Making of the Intellectual and Humanist Movement (Edinburgh: Edinburgh University Press, 2013). The reply from Islamic reformist Muḥammad 'Abduh to secularist journalist Faraḥ Anțūn from 1901 is seminal in this respect, commonly titled al-Islām wa-l-nașrāniyya. Ma'a alilm wa-l-madaniyya (Islam and Christianity. In relation to Science and Civilisation): Muḥammad 'Abduh, "al-Radd 'alā Farah Anțūn. al-Iḍțihād fì l-nașrānīya wa-l-islām", in al-A'māl al-kāmila li-l-Imām al-Shaykh Muḥammad 'Abduh, ed. Muḥammad 'Imāra, 2nd ed., 5 vols. (Cairo: Dār al-Shurūq, 2006), vol. 3, 257-376; see also Ammeke Kateman, Muhammad 'Abduh and His Interlocutors: Conceptualizing Religion in a Globalizing World (Leiden: Brill, 2019), 253-57.

23 al-Batanūnī, al-Rị̣la al-Hijāzìyya, 11.

24 Perhaps this is typical of modern Islam, contrasted with the tolerance of "ambiguity" in pre-modern Islamic culture - as Thomas Bauer suggested in: Die Kultur der Ambiguität: eine andere Geschichte des Islams (Berlin: Verlag der Weltreligionen, 2011).

25 al-Batanūnī, al-Rihla al-Hijäziyya, 11. al-Batanūnì's simple and only truth for all might have also fitted in broader trends within modern Islam or even the modern period. It can be considered an example of what Shahab Ahmed calls a twentieth-century and typically modern Islamic "social egalitarianism of truth", in its unambiguity and simplicity aimed at the public. This idea of a monolithic, homogeneous truth for all, public and private, is very different, according to Ahmed - and Thomas Bauer, too - from the notions of truths that predominated in pre-modern Islamic societies. The pre-modern epistemology allowed for multiple levels and dimensions of knowledge, complexity, and ambiguity of meanings, paradoxically stemming from the social hierarchies and elitism it reflected and produced: Shahab Ahmed, What Is Islam? The Importance of Being Islamic (Princeton: Princeton University Press, 2016), 521, 537; cf. Bauer, Die Kultur der Ambiguität, 46-49. 
In the remainder of his travelogue, al-Batanūnī does not regularly contrast his representation with that of others. At times, however, he intersperses his sections on the urban geographies of the hajj places with more explicitly subjective observations, expressing his shock at certain practices he encounters, often with multiple exclamation marks. It is in these evaluations, in which he actively contests other interpretations and categorically presents his interpretation as correct and others as incorrect, that his specific fashioning of the hajj becomes most evident. The next section will focus on al-Batanūnī's representation of these contested hajj matters, which more often than not deal with an aspect related to what is called here the "materiality" of the hajj. The subsequent section on refiguring others will then discuss al-Batanūnīs views on reforming hajj understandings and practices he considers to be misinformed.

Before continuing, it is pertinent to note that these heated moments of contestation were not the only instances that allowed for emotion in al-Batanūnì's factual travelogue. As mentioned in the description of the contents of his text, al-Batanūnī pays quite some attention to his and his party's emotional state in Mecca and Medina. ${ }^{26}$ In a particularly sensational passage, al-Batanūnī recounts the experience of him and his party stretching their necks to see the crescents on the minarets of the Prophet's mosque as they approach Medina. He elaborately relates the emotion and sensation of delight and rush in their heart, breasts, eyes, and minds when they finally see the contours of the Prophet's city. They rejoice, pray, and incessantly utter labbayka and allähu akbar, for example, while their souls are "fluttering in their vessels", being lifted from their ordinary bodies. ${ }^{27}$ al-Batanūnī describes these and other feelings as collective experiences, mostly felt uniformly by the whole group in which he travels, or, when discussing a sense of shock and fear at seeing the Ka'ba, even by "anyone who sees the Ka'ba for the first time". ${ }^{28}$

This type of overt emotionality seems to be somewhat at odds with the descriptive factuality of most other parts. On the other hand, lyrical descriptions such as these are not alien to the genre of hajj travelogues; other pilgrimage accounts to the Hijāz also contain poetical and ecstatic descriptions of the emotions and sensations felt at Mecca and Medina. ${ }^{29}$ Furthermore, Abū

26 al-Batanūnī, al-Rihla al-Hijäziyya, 91-92, 176, 235-36, 30o. For an English translation of one of these passages on the pilgrims' particularly emotional experience at the Ka'ba, see A.J. Wensinck, “Ka'ba", in E.J. Brill's First Encyclopaedia of Islam, 1913-1936, ed. M. Th. Houtsma et al. (Leiden: Brill, 1993), vol. 4, 588.

27 Ibid., 300.

28 Ibid., 176 .

29 Nasser S. al-Samaany, "Travel Literature of Moroccan Pilgrims during the 11-12th/17-18th Centuries: Thematic and Artistic Study" (PhD Dissertation, University of Leeds, 200o). 
Ḥāmid al-Ghazālī, too, emphasises the interior cultivation of proper hajj emotions in his treatise on the ritual of the hajj. ${ }^{30}$ al-Batanūnī's bouts of emotionality, as well as the particular emotional expressions that he reports in his travelogue, such as crying at the Ka'ba or yearning to see Medina and be close to the Prophet, thus seem to follow established and expected patterns.

\section{Presenting a Proper Materiality of the hajj}

Even though hajj rites (pl. manāsik) are regulated in detail by the four Islamic schools of law, and their meanings discussed elaborately in the hadith literature and classical scholarship, there is some variation in what is prescribed and in the meanings given to the various elements. Focusing on the pre-modern normative tradition, Marion Katz describes the variety of equally authoritative positions on the efficacy of the rituals - for example whether rituals work in an "ethical" or "sacramental" way - and on the (lack of the) role of myth - for example whether this role is commemorative only or also refers to the reliving or reviving of a mythical past and its figures. ${ }^{31}$ She argues that "there is no single model [of the hajj] that accounts for all the different elements and configurations" and that, instead of looking for an essentialising definition, scholars should care about dissecting and analysing these debates. ${ }^{32}$ In addition to the variation within what is normatively and authoritatively prescribed, which is what Katz focuses on, there is also obvious variation in the hajj practices and interpretations that are related to, yet also go beyond, what is prescribed. The hajj is implemented, given meaning, and added to in what might be called the "lived" reality of Muslims performing rituals, yielding further variation in how hajj rituals are interpreted and practised.

al-Batanūnī explicitly announces in his introduction that he wishes to set some facts about the hajj straight. Inspired by Marion Katz's redefinition of the hajj as a set of debates, this section analyses al-Batanūnì's explicit contestations of those practices and interpretations he deems incorrect - especially in

30 See, e.g., al-Ghazālī on "desire" (shawq) as an internal prerequisite for performing the hajj: Abû Hamid al-Ghazâlî, Les Secrets du Pèlerinage en Islam: Avec un commentaire des cinq piliers de l'Islam [Revivification des sciences de la religion], trans. Maurice Gloton (Beirut: Albouraq, 2001), 128, 156. See also Anna Gade on Islam and emotions in more general: Anna M. Gade, "Islam", in The Oxford Handbook of Religion and Emotion, ed. John Corrigan (Oxford: Oxford University Press, 2007).

$3^{1}$ Marion Katz, "The Hajj and the Study of Islamic Ritual", Studia Islamica, 98/99 (2004), 100-21. 
matters of hajj materiality - in order to relate his representation of the hajj to the contemporaneous debates about the hajj. Thus, it situates al-Batanūnīs representation of the hajj and its materiality in the debates about the hajj within the Muslim community of his time - and not so much vis-à-vis the Islamic tradition and its authorities, as Katz does. We will see in the concluding section, however, that the debates about the hajj did not take place only amongst Muslims; in his hajj account, al-Batanūnī equally evaluates and contests nonMuslim interpretations of the hajj. By positioning al-Batanūnīs interpretation within these debates within and beyond Islam, this article aims at a better sense of the contemporaneous particularity of al-Batanūnìs fashioning of the hajj.

"And this belief still exists!" al-Batanūnī exclaims after describing how some Muslims believe that a cleft in a cave near Minā was made by Ibrāhīm's knife, when he attempted to sacrifice his son, instead of by a natural cause. ${ }^{33}$ On another occasion, he elaborately decries the veneration of certain rocks on the route between Jedda and Mecca, about which muțawwifs (hajj guides) relate that these were people turned into stone. ${ }^{34}$ Many exclamation marks also indicate his surprise or offence at other Muslims' interpretations of another aspect of the material world of the hajj, the Zemzem well and its water. He refers to the Meccans working at the well who claim, pointing to a hadith, that the water is beneficial for everything (even alleviating hunger). He also lists the Zemzem practices of Indians, who take home a piece of cloth immersed in Zemzem water in order to take it into their graves, or the belief of some Egyptians that specific wells in Egypt connect to the Zemzem well. In contrast, al-Batanūnī finds the reverence (ihtirām) for the Zemzem water excessive, an erroneous type of belief that exists among those who are ignorant. ${ }^{35}$

al-Batanūni's "problem" with beliefs and practices concerning the materiality of the hajj connects to several discourses and, simultaneously, reveals the way he presents the hajj in his travelogue. First, it often intersects with his concern for public hygiene, according to the latest scientific insights of his time. For example, al-Batanūnī considers it a "horrific belief" that people from India take home dried pieces of the slaughtered meat from the Feast of the Sacrifice ('id al-adha $\bar{a}$ ). They clearly have no knowledge of microbes, he sighs. ${ }^{36}$ Similarly, he is pleased with the sharif s ban on lepers bathing in the well of Zubayda for its water's supposedly healing powers, as bacteriologists argue

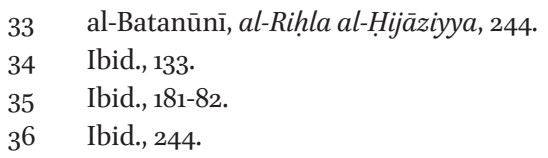


that contaminated water is especially likely to spread cholera. ${ }^{37}$ Science also provides al-Batanūni with a definitive answer on the beneficial nature of the water of the Zemzem well. "The reality" (al-haqìqa) is, al-Batanūnī writes, that the water is particularly alkaline and contains all kinds of minerals. Given this chemical truth, Zemzem water is not especially beneficial and can even be harmful, especially outside the hajj season, because Meccans do not drink it themselves. ${ }^{38}$

al-Batanūnīs concern for the sanitary conditions of the hajj in relation to its materiality becomes also manifest in his assessment of the health infrastructure of the ritual places. He deplores the water facilities in Mecca and Yanbu', for example, but also the lack of proper hospitals and medical services. ${ }^{39} \mathrm{On}$ the other hand, he is very content with the establishment of quarantine stations at al-Ṭurr, in the Sinai Peninsula, and Kamarān, in the Red Sea, in order to prevent diseases from spreading, which, in his view, were perfectly organised by the Egyptian authorities (which he happened to work for). ${ }^{40} \mathrm{He}$ urges the khedive to further concern himself with setting up hospitals and water filtration systems, especially for the benefit of the Egyptian poor. ${ }^{41}$ Finally, in his exposition on the ritual garment, he stresses that the ihrām dress is certainly not the cause of sicknesses. ${ }^{42}$ His preoccupation with the hajj and its water and health infrastructure, especially as a problem for the "paupers" and an occasion for pandemics, is certainly not unique to al-Batanūnī; it was a concern widely shared in this epoch and was one of the main focuses for colonial and other authorities at this time. ${ }^{43}$

37 Ibid., 232-35. Cf. al-Batanūnīs displeasure (ibid., 177) with other occasions in which contagious diseases were likely to spread. For example, he mentions how Indian pilgrims carry their elderly and sick on stretchers around the Kaba. These sick and old pilgrims hope to die there and then, according to al-Batanūnī, and are (unfortunately, for alBatanūnī) not concerned with the diseases they are spreading.

38 Ibid., 181. On the other hand, he includes the drinking of Zemzem water amongst his listing of the hajj rituals anyway. Ibid., 218.

39 Ibid., 137-39, 357.

40 Ibid., $137,357-62$.

41 Ibid., 311, 357.

42 Ibid., 126.

43 William R. Roff, "Sanitation and Security. The Imperial Powers and the Nineteenth Century Hajj", Arabian Studies 4 (1982), 143-6o; Cornelia Essner, "Cholera der Mekkapilger und internationale Sanitätspolitik in Ägypten (1866-1938)", WI 32 (1992), 41; Michael Low, "Empire and the Hajj: Pilgrims, Plagues, and Pan-Islam Under British Surveillance, 18651908", IJMES 40:2 (2008), 269-9o; Saurabh Mishra, Pilgrimage, Politics, and Pestilence: The Haj from the Indian Subcontinent, 1860-1920 (Oxford: Oxford University Press, 2011); Luc Chantre, "Entre pandémie et panislamisme: L'imaginaire colonial du pèlerinage à La Mecque (1866-1914)", Archives de sciences sociales des religions, 163 (2013), 163-9o; 
Second, in addition to this dimension of health and public hygiene, his denunciation of aspects of hajj materiality seems related to his dislike of what he considers an excessive care (mubälagha) for decoration, especially concerning the kiswa (the cloth, made annually, draped over the Ka'ba) and the mahmal. ${ }^{44}$ In contrast to al-Batanūnī's negative assessment of excessive decoration, he appreciates a sober materiality in the service of spirituality. He elaborately praises the simplicity and order of the home of Muhammad's first wife and first Muslim convert, Khadija, which was stripped of external splendour. This simple order (nizām) was also what Egyptian civilisation was built on, he writes. Furthermore, Khadija's home symbolised the importance of religious contemplation, instead of luxury and richness, for the Prophet (and in Islam in general). 45

al-Batanūnī's emphasis on Islam's material simplicity reappears on other occasions in his travelogue and is connected to the ideals of (social) justice, brotherhood, and equality. ${ }^{46}$ In describing the i $i$ rām, white and unstitched, al-Batanūnī presents its simplicity as a sign of detachment of the world's vanities and as a symbol of true socialism (ishtirākiyya). ${ }^{47}$ Similarly, following his exposition of the standing (wuqūf) at 'Arafât, al-Batanūnī describes the revitalising effect of the hajj on Muslim leaders and the rich, as they mix with the commoners and become concerned with the plight of the poor and the wretched and turn away from oppression and towards socialism. ${ }^{48}$ Similarly,

Chiffoleau, Le Voyage à La Mecque, chap. 4; John Slight, The British Empire and the Hajj: 1865-1956 (Cambridge, MA: Harvard University Press, 2015); Eric Tagliacozzo, The Longest Journey: Southeast Asians and the Pilgrimage to Mecca (New York: Oxford University Press, 2013), chap. 6; Islam and the European Empires, ed. David Motadel (Oxford: Oxford University Press, 2014), chap. 2 and 3; Michael Christopher Low, "Ottoman Infrastructures of the Saudi Hydro-State: The Technopolitics of Pilgrimage and Potable Water in the Hijaz", Comparative Studies in Society and History 57:4 (October 2015), 942-74; Eileen Kane, Russian Hajj: Empire and the Pilgrimage to Mecca (Ithaca, NY: Cornell University Press, 2015). al-Batanūnī, al-Rihla al-Hijazziyya, 187-88, 189, 193. On the other hand, he does express his appreciation of the music accompanying the mahmal caravan: Ibid., 311. In Cairo's reformist circles, the kiswa and mạ̣mal also raised questions. Rashīd Riḍa conceived of the kiswa and the mahmal as not essential to Islam, as bid'a (innovation), yet not necessarily harmful. See Charles C. Adams, Islam and Modernism in Egypt: A Study of the Modern Reform Movement Inaugurated by Muhammad Abduh (London: Oxford University Press I Humphrey Milford, 1933), 19o; "Shaykh al-Azhar, wa-zīnat al-kiswa wa-l-maḥmal, ḥukm al-furja 'alayhā", al-Manār 8:21 (1905), 839-40.

45 al-Batanūnī, al-Rihla al-Hijāzìyya, 98.

46 Cf. Ibid., 296.

47 Ibid., 225-26.

48 Ibid., 214-15. According to al-Batanūnī, such a concern for social justice and equality was also the effect the hajj had on the khedive. I consider his description of this effect one of the ways in which al-Batanūnī fashions a favourable public persona of his patron 
on several occasions, he considers various rituals of the hajj to have a unifying effect, engendering a sense of communal unity as well as internal equality. ${ }^{49}$ He shares this emphasis on socialism with other Arabic intellectuals of the nahda period, Muslim and non-Muslim alike. ${ }^{50}$ Thus, al-Batanūni’s treatment of hajj materialities linked with a preference for a sober order, an aversion from externalities, and sympathy for social justice.

It also resonated with contemporary critiques of external aspects of tombs. The Cairo-based Islamic reformist Muḥammad Rashīd Rị̣ā was particularly vocal in this respect. Riḍa opposed the practice of material additions and decorations at tombs because he thought these ornamentations would tempt the believer to treat tombs as places of worship and veneration instead of inviting reflection and contemplation (for which Riḍa considers them a form of wrongful bid'a). ${ }^{51}$ Ridâ’'s concern that these places and objects too easily invited being worshipped themselves also relates to the "ontological status" of the saints buried at those tombs which were decorated with domes and other material additions. ${ }^{52}$

Indeed, thirdly, al-Batanūnī's problems with an (excessive) materiality of the hajj and his interpretation of a proper attitude towards things and matter also concern the "ontological status" of hajj matters. For example, according to him, the material facts about the benefits of the Zemzem water lie in its chemical constitution, as we have seen, not in whatever qualities Meccans attribute to it (even though they quote a hadith to corroborate their view). On the other hand, al-Batanūnī includes the drinking of the Zemzem water in his ritual prescriptions for the pilgrims. ${ }^{53}$ Similarly, alongside his ridiculing of people's belief that the cleft in the cave near Minā was not a natural occurrence but a

according to the conventions and norms of his historical context. See also above for other ways in which he fashioned a particular public persona of the khedive.

49 Ibid., 91-92, 175-76, 213-14, 316-19.

50 Ilham Khuri-Makdisi, "The Nahḍa Revisited: Socialism and Radicalism in Beirut and Mount Lebanon, 1900-1914", in Liberal Thought in the Eastern Mediterranean: Late 19th Century Until the 196os, ed. Christoph Schumann (Leiden: Brill, 2008), 147-74; Ilham KhuriMakdisi, The Eastern Mediterranean and the Making of Global Radicalism, 1860-1914 (Berkeley: University of California Press, 2010); Ilham Khuri-Makdisi, "Inscribing Socialism into the Nahdia. al-Muqtataf, al-Hiläl, and the Construction of a Leftist Reformist Worldview, 188o-1914", in The Making of the Arab Intellectual: Empire, Public Sphere and the Colonial Coordinates of Selfhood, ed. Dyala Hamzah (Milton Park: Routledge, 2013), 63-89. Richard Van Leeuwen, "Reformist Islam and Popular Beliefs: Rashîd Ridâ's Attack against the Cult of Shrines", in Sources and Approaches across Disciplines in Near Eastern Studies: Proceedings of the 24th Congress, Union Européenne des Arabisants et Islamisants, Leipzig 2008, ed. Verena Klemm and Nuha al-Sha'ar (Leuven: Peeters, 2013), 146-48.

52 Ibid., 148-51.

53 al-Batanūnī, al-Riḥla al-Hijāziyya, 218. 
direct result of Ibrāhīm's attempt at sacrificing his son, he does seem to want them to acknowledge and commemorate that Ibrāhīm chose this place originally. ${ }^{54}$ The ambivalence of al-Batanūnì's position on these and other hajj matters seems to hinge on his idea of what constitutes a proper belief in and attitude towards them, both ontologically and functionally.

His vision becomes most explicitly manifest in his defence of certain material aspects of the hajj against the allegations of others, both within and outside Islam. His explanation of the proper Islamic attitude towards Islamic materialities first becomes manifest in his exposition on Jedda and surroundings, where he discusses the tomb of "our mother" Hawwā' (Eve), which sharif 'Awn al-Rafiq (r. 1882-1905) had planned to demolish until European consuls intervened. ${ }^{55}$ Contesting the views of this shariff as well as contemporary Wahhābì-Sa'ūdī interpretations and their early nineteenth-century demolitions of tombs, al-Batanūnī writes that, upon its arrival, Islam eradicated every trace of polytheism and idolatry (shirk and wathaniyya), tearing down the temples. What was left was only a reverence (birr) for the truth of [Eve's] motherhood in the souls of people, who then erected a domed shrine (qubba) solely as a place to visit (mazār), similar to what they had done for the graves of the Prophet's kin. ${ }^{56}$ Indeed, the visitation of such tombs was manifestly unproblematic for the khedive and his party, who visited many domes and cemeteries while in Mecca and Medina, as well as other buildings connected to Islam's sacred history. ${ }^{57}$

al-Batanūni's position on the correct interpretation of the ontological status of objects and attitude towards them becomes clearer, however, in his much more elaborate contestation of yet another interpretation of hajj matters, this time coming from outsiders. In his introduction, he promises to expose the facts, free from the prejudices (sg. gharad), errors (sg. wahm), or shams (sg. turraha) that "enemies of Islam" use to slander the religion. ${ }^{58}$ In his discussion of the Black Stone, it becomes clear that his introduction alludes to some Christians who interpret its veneration (ihtirām) as a remnant of pre-Islamic

\footnotetext{
54 Ibid., 244.

55 Perhaps sharif' Awn al-Rafiq's intention to demolish this and other tombs was inspired by the Wahhābīs' destruction of tombs, especially as some earlier shariffs thought that this iconoclastic aspect of the Wahhābi movement was part of the explanation for their strength: al-Batanūnī, 148. The tomb of Eve was later, in 1926, closed by the Wahhābīs under 'Abd al-'Azīz Āl Sacūd (Ibn Sacūd). William Ochsenwald, "Islam and Loyalty in the Saudi Hijaz, 1926-1939", WI 47:1 (2007), 13.

$5^{6}$ al-Batanūnī, al-Rị̣la al-Hijāzizyya, 78-81. On the Wahhābī actions in Mecca, see ibid., 148.

57 Ibid., 97-100, 101, 128-29, 308, 311.

58 Ibid., 11.
} 
paganism (wathaniyya). ${ }^{59}$ To counter this interpretation, al-Batanūnī begins a long exposition on examples of the use of stones amongst pre-Islamic Arabs, as well as other peoples from all around the world. ${ }^{60} \mathrm{He}$ concludes that the stones are revered for their relation to something holy, not in and of themselves. The veneration of the Black Stone is no different, for which he cites a hadith in which 'Umar is said to have approached it, kissed it, and commented, "I know that you are a stone, you do not cause benefit or harm; and if it were not that I had seen Allāh's Messenger - peace and blessings of Allāh be upon him - kiss you, I would never have kissed you." ${ }^{61}$ According to al-Batanūnī, the Black Stone instead functions as a reminder of Ibrāhīm's (or Abraham's) fulfillment of his Lord's wishes. Alternatively, it reminds of Ibrāhīm's agreement to establishing this house as a place of worship, for which purpose he pragmatically placed a black stone to indicate the beginning of the circumambulation. ${ }^{62}$ As a symbol ( $\mathrm{ramz}$ ) of God's sovereignty, the Black Stone receives a type of respect similar to that which national flags get, al-Batanūnī explains, even though these flags are obviously nothing more than a piece of cloth on a simple pole. ${ }^{63}$ Incidentally, Marion Katz explains that this idea of the "symbolism" of certain rites and ritual objects - in order to explain that which cannot be expressed in words in Islamic ritual - only appears and becomes increasingly dominant in the modern period. ${ }^{64}$

For al-Batanūnī, these objects perhaps function in a way similar to certain hajj rituals. In discussing the stoning of the devil, al-Batanūnì explains (reminiscent of al-Ghazālī) that meaning and materiality are intertwined. The act of bodily stoning generates the right belief and instills an according character trait (malaka), which is, in this case, one's opposition to the devil and shunning of evil. ${ }^{65}$ This type of moral formation (tahdhïb) is also the effect of the hajj in general, according to al-Batanūnī, rendering the pilgrim immune to the devil's

59 Ibid., 210. This type of "allegation" is also refuted in other Mecca travelogues in the first half of the twentieth century, indicating the prevalence of this argument, as well as the resistance to it. See, e.g., Mușțafā Muhammad al-Rā̄î̀, Fì l-Mamlaka al-rūḥiyya li-l-'ālam al-islāmì: Riḥla ilā al-arḍ al-muqaddasa 'àm 1349 hijriyya 1931 mïlādiyya (Cairo: Maṭba'at al-Madina al-Munawwara, 1932), 52.

6o al-Batanūnī, al-Rihlla al-Hijäziyya, 205-og.

61 Ibid., 210. For references to the Black Stone in classical hadith compilations, see A.J. Wensinck, A Handbook of Early Muhammadan Tradition. Alphabetically Arranged (Leiden: Brill, 1927), 220.

62 al-Batanūnī, al-Riḥla al-Hijāziyya, 209.

63 Ibid., 210.

64 Katz, "The Hajj and the Study of Islamic Ritual", 125-26.

65 al-Batanūnī, al-Riḥla al-Hijäziyya, 240. 
seductions. ${ }^{66}$ The rituals of the hajj, as well as its materiality, are thus functionally and not so much ontologically related to the religious and the sacred. Once properly interpreted, however, materiality is (and should be) an integral aspect of the hajj for al-Batanūnī. ${ }^{67}$

Thus, hajj-related objects - the Black Stone, for example, but also the graves of Hawwä' and others, as well presumably the Zemzem water and the cave in which Ibrāhīm intended to sacrifice his son Ismācil - are special for their relation to something sacred. They are worthy of respect and veneration because of what they symbolise - yet one should not overdo it and attribute them an ontological sacredness, decorate them excessively, or jeopardise public hygiene. With his representation of hajj materiality, al-Batanūnī links up with contemporary debates and practices about public hygiene, order, and rationality and navigates amongst contemporaries who believe in a more direct link between the material and the spiritual, as well as others who wish to shun hajj matters much more completely.

\section{Refiguring Others}

In the introduction to his book, al-Batanūnī writes that the "slanderers" of Islam - for example, those who conceive of the veneration of the Black Stone as a remnant of paganism - rely for their interpretations and allegations on Muslims who are ignorant of their own religion and who randomly pick from its theology. ${ }^{68}$ This suggests that al-Batanūni’s wish to refute false allegations of malevolent outsiders about hajj matters ties in with his desire to counter ignorance and misinterpretations amongst Muslims, for instance those related to the Zemzem well.

al-Batanūnīs own interpretation of the hajj and its materiality seems one way to consciously solve this two-tiered problem. Explaining the "proper" interpretation in a simple, factual, and scientific manner, and often explicitly

66 Ibid., 215. For al-Batanūnī, additional morally edifying effects of the hajj seem to be the engendering of a sense of unity and equality, see above.

67 Even though "only" symbolic or functional, Islamic reformists like Muhammad 'Abduh emphasised the importance of this relation between outward and inward, ritual and belief, moreover. He condemned the performance of rituals that were not sufficiently connected to interior beliefs and intentions. Johanna Pink, "Abduh, Muhammad", in Encyclopaedia of the Qur'ān, ed. Jane D. McAuliffe (Brill Online, 2015), <http://referenceworks. brillonline.com/entries/encyclopaedia-of-the-quran/abduh-muhammad-EQCOM_o5o $483>$. 
contesting other interpretations, it is meant to educate those who believe and act differently.

Travel narratives like al-Batānūn̄̄'s perform "communicative acts" and (intend to) have effects on their audiences and eventually their realities - what Nünning would call the aspect of "refiguration". ${ }^{69}$ As hajj travelogues are being read, they co-build the anticipations of others, co-tuning their minds and senses to attribute certain words and feelings to the pilgrimage and the journey, to make sense of it all, functioning in this way alongside many other visual, textual, and oral mediations of the hajj (tiles, murals, stories, songs, manuals, etc.). ${ }^{70}$ In addition, travelogues' authors often anticipate and intend to have an effect on their readers. al-Batanūin was no different. It is in this sense, too, that his travelogue is "reformist", in that it consciously tries to fashion Islam, the hajj, and its materiality as particularly compatible with science, rationality, and civilisation, both to other Muslims and outside observers, fitting in with the contemporaneous reform projects of the nahda and Islamic reformism in a colonial age.

Apart from the reformist intentions of his travelogue, al-Batanūnī sees potential in an improvement of the knowledge infrastructure in Mecca and (to a lesser extent) Medina, decrying the quality of the schools, libraries, and presses there. ${ }^{71}$ Although one might expect that Meccans would be considered to have "original" knowledge of Islam, being closest in proximity to the Kaba and the birthplace of Islam, they, according to al-Batanūnī, are clearly not knowledgeable about religion. In contrast, he thinks better of Medinans' ethical standards, which is unsurprising given that he presents Medinans as the successors of the initial "Helpers" (anșār) of the Prophet Muhammad. ${ }^{72}$ Meccans, on the other hand, only care to make money from the pilgrims, especially by making

69 El-Sayed, "Discourses on Emotions", 40, referring to the work of Gabriele Jancke; Nünning, "Wirklichkeitsdarstellung im Reisebericht", 14.

70 Cf. Birgit Meyer on the senses being "tuned" and specific religious experiences and sensations thus being "made" and transmitted through religious media: Birgit Meyer, "How to Capture the 'Wow': R.R. Marett's Notion of Awe and the Study of Religion", Journal of the Royal Anthropological Institute 22:1 (2016), 17-18; Birgit Meyer, "Media and the Senses in the Making of Religious Experience: An Introduction", Material Religion 4:2 (2008), 129. al-Batanūnī, al-Riḥla al-Hijāziyya, 131-37, 348, 351. Cf. Werner Ende, "Medina und seine Bibliotheken in spätosmanischer Zeit", in Osmanische Welten. Quellen und Fallstudien. Festschrift für Michael Ursinus, ed. Johannes Zimmermann, Christoph Herzog and Raoul Motika (Bamberg: University of Bamberg Press, 2016), 129-5o.

Ibid., 351. In comparison with the Meccans, al-Batanūnī is equally critical of some of the Bedouin tribes of the Arabian Peninsula, for example because some of them consider the hajj complete without the wuqūf at 'Arafāt: ibid., 212. It is clear that they do not represent the "authentic" Islam for him, as a good number of orientalist travel writers represented them at that time. See Melman, "The Middle East / Arabia: "The Cradle of Islam."” 
use of - yet again - hajj objects, for example the brooms with which the Kaba is cleaned, or by exaggerating the benefits of Zemzem water without any proper knowledge of its chemical constitution. ${ }^{73}$ Especially hajj guides should be trained properly to prevent them from teaching the pilgrims erroneous interpretations and practices, such as their stories about men who were turned to stone on the road to Mecca, and their wrongful pronunciation of Qurānic ritual formulas. ${ }^{74}$

Many of the Muslims whose practices and beliefs al-Batanūnì explicitly targets are particularly poor, suggesting a class aspect to his dislikes. ${ }^{75}$ They are also relatively often of Indian origin, perhaps indicating an element of racism, but these pilgrims often happened to be particularly poor, too. ${ }^{76}$ At times, alBatanūnī considers their poverty an explanation for their lack of knowledge and hygiene. For example, even if Indian pilgrims knew about microbes, alBatanūnī thinks they would probably take home dried pieces of slaughtered meat anyway, because of their extreme poverty. ${ }^{77}$ Similarly, he describes how Javanese teachers in Mecca are too poorly paid to teach adequately. ${ }^{78}$

Poverty relief and charity thus seem to be ways, too, to correct wrongful interpretations and practices concerning the hajj and its materialities. His aforementioned pleas to the Egyptian khedive, as well as to the Ottoman government, to improve the plight of the poor, to found hospitals, hostels, and soup kitchens, also seem to fit with this concern of his. ${ }^{79}$ Indeed, al-Batanūni describes the experience of the hajj itself, and especially the standing at 'Arafāt, as instilling a concern for the poor amongst Muslim leaders. ${ }^{80}$ Elaborately comparing the situation of the destitute in Jerusalem and Mecca, he also calls on all Muslims (especially, Egyptian Muslims) to donate money to establish a charity for the poor in Mecca. ${ }^{81}$ In addition to the direct corrections to others' practices and

73 al-Batanūnī, al-Rihla al-Hijāziyya, 134-36, 166, 194.

74 Ibid., 133. From the mid-192os, Ibn Sa ūd especially targeted the mutawwifs, too, in his attempt to reform the hajj. See John M. Willis, "Governing the Living and the Dead: Mecca and the Emergence of the Saudi Biopolitical State", The American Historical Review 122:2 (2017), 346-70.

75 Interestingly, al-Batanūnī does not target Shīīi interpretations and practices (although he sometimes notes differences; see, e.g., al-Batanūnī, al-Rihla al-Hijäziyya, 235). These do not seem to form a "problem" for him, certainly not as much as the practices of the Indian poor Sunnīs do.

${ }_{76}$ On the modern category of the Indian pauper pilgrim and British imperial policies concerning these pilgrims, see Slight, The British Empire and the Hajj, chap. 2.

77 al-Batanūnī, al-Rihla al-Hijäziyya, 244.

78 Ibid., 134.

79 Ibid., 131, 132, 133, 134, 137, 357.

8 o Ibid., 213-14.

81 Ibid., 140-44. 
interpretations the travelogue entails, these pleas for charity and a better educational infrastructure are part of al-Batanūnı̄s attempts to reform the hajj more indirectly.

In considering the extent of this refiguration - that is, the (potential) impact of the travelogue on outside reality, especially its contemporaneous readers it should be noted that al-Batanūni's account seems to have been a rather widely read hajj travelogue, as is indicated by its republication, revised by the author himself, and its reprints. Furthermore, it was positively and elaborately reviewed in al-Manār (edited by Rashīd Riḍā), as mentioned above. ${ }^{82}$ Riḍā also referred to al-Batanūnìs travelogue in his account of his own hajj journey in 1916, as did the Egyptian hajj commander Ibrāhīm Rif'at Bāshā in the mid1920 in his travelogue. ${ }^{83}$ Further evidence that al-Batanūn's account was actually read, at least in reformist circles inside and outside of Egypt, is that it is discussed in Khayr al-Dīn al-Ziriklîs's Mecca travelogue in 1929, as mentioned above.$^{84}$ Lastly, a significant number of copies are still extant, which is probably the reason why the travelogue is relatively often used as a source for historical studies on the hajj (some of which have been referred to above).

\section{Concluding Remarks}

In his travelogue al-Rihla al-Hijäziyya of 1911, the Egyptian travel writer Muhammad Labīb al-Batanūnī consciously fashions the hajj, especially its materiality, reflecting the debates of his time and participating in them. His configuration of the hajj in this travelogue is strongly factual and aims to demonstrate Islam's compatibility with scientific rationality.

This impression of veracity also colours and boosts the way in which alBatanūnī contrasts his presentation of the hajj with other Muslims' beliefs and practices, as well with outsiders' interpretations. In contrast with those pitifully ignorant others, al-Batanūnìs position is presented as one of rational facts, whether originating in Islamic authoritative texts or in secular knowledge. By presenting the hajj in contestation with the interpretations and practices of others, especially those who are poor and uneducated, his factual presentation of the hajj at the same time becomes the hajj of the modern,

\footnotetext{
$82 \quad$ See above, note 18.

83 Brunner, "Pilgrim's Tale as a Means of Self-Promotion", 277; Stratkötter, Von Kairo nach Mekka, 22, n.26. Travelling a couple of years before al-Batanūnī, Ibrāhīm Rif'at Bāshā only published the accounts and photographs of his early twentieth-century journeys in the 1920 .

84 See above, note 21.
} 
educated Muslim. He handles hajj matters in an orderly manner, compatible with the latest insights and rationality, unlike the superstitious and ignorant interpretations and unhygienic practices of the Muslim poor, whom he wishes to reform, and equally unlike outsiders' allegations that the hajj contains a (primitive and irrational) pagan belief in stones. This presentation of the modernity and rationality of the hajj was especially relevant in a context of colonialism, in which French, British, and Dutch intellectuals and scholars regularly wrote off Islam as a remnant of the past and Muslims as irrational, often functioning as a pretext for the colonial conquest and subjugation of Muslims. ${ }^{85}$

For al-Batanūnī, the context that has shaped his text, and which he intends to shape with his text, was indeed in many ways global. In presenting an alternative to the materiality he encounters, he refers to globally circulating theories and concerns about public health and social justice and also to universal histories of peoples and religions. So, as mentioned above, he situates the symbolic veneration of the Black Stone within human history at large, referring to the historical use and contemporary veneration of stones by Jews and Christians, for example, as well as the respect for ordinary things, such as flags by contemporary European nations. ${ }^{86}$ Similarly, amongst other examples, the respect for Zemzem water is likened to the importance that many Christians attach to Lourdes water or Hindus to the Ganges River. Also, the ihramm cloth is juxtaposed with a long history of ancient Egyptian, Assyrian, Greek, and Jewish dress, while the benefits that come with this simple garment are likened to the wholesome exposure to air at health retreats in the mountains or at the seaside. ${ }^{87}$

Indeed, the fact that "materiality" was so much of a problem for al-Batanūnì fits in with the globalisation of the modern concept of religion from the late nineteenth century. ${ }^{88}$ Intellectuals around the world increasingly shared a set of themes, discussions, or problems in the way they interpreted religion. One

85 In the French context, one might think of the work of a scholar and public intellectual such as Ernest Renan, but also of lesser known littérateurs and politicians such as Daniel Kimon or Gabriel Hanotaux, whose contributions have been heavily debated in the Arabic press, too. See, for a recent example of such arguments, Dietrich Jung, Orientalists, Islamists and the Global Public Sphere: A Genealogy of the Modern Essentialist Image of Islam (Sheffield: Equinox, 2011).

86 al-Batanūnī, al-Riḥla al-Hijāziyya, 205-10.

87 Ibid., 181-82, 223-27. For more examples of the way al-Batanūnī employs a universal framework in his exposition of the hajj, see ibid., 178, 194, 203-04, 240.

88 On the globalisation of the modern concept of religion in the Islamic world, see Jung, Global Public Sphere; Armando Salvatore, Islam and the Political Discourse of Modernity (Reading: Ithaca, 1997). 
of the hotly debated globalising problems was the question of materiality and religion, mirroring the importance of this issue within and beyond Protestantism, especially in contradistinction with Roman Catholicism. ${ }^{89}$

al-Batanūnī sees no tension between this global dimension and Islam. He seamlessly fits Islam and its framework of knowledge and normative texts on the hajj and its materiality within knowledge structures that were at least not particular to Islam, seemingly convinced of the claims to universalism of Islam, science, and global modernity alike. It is in this global sense that his travelogue participates in the debates about the hajj within, as well as beyond, Islam. On the one hand, his representation of the hajj, especially hajj matters, hinges upon implicitly and explicitly contesting the beliefs and practices of other Muslims. Contrasted with the irrationality, excessiveness, and poor hygiene of the poor, he defines the hajj in a way proper to the civilised, educated, and orderly Muslim. On the other hand, his image of the hajj is also related to its differentiation from non-Muslim interpretations of the Black Stone and its comparability with other religious and non-religious practices from all over the world and from throughout history. By attributing the Black Stone a purely symbolic function, he refutes the allegations that the materiality of the hajj is pre-Islamic and pagan (and thus perhaps primitive and incoherent). As the symbolism of stones is common to all mankind, according to al-Batanūnī, he presents the hajj in a way that is at least on a par with, if not superior to, other religions' practices and which is completely compatible with the conventions of that global age.

Several of the aspects of al-Batanūni's unambiguous fashioning of the hajj and the ways he wrestles with the question of materiality find an echo in the Sa ūdī-Wahhābī governance of the hajj since the mid-1920s. ${ }^{90}$ Even though alBatanūnī considers Muhammad b. 'Abd al-Wahhāb's eighteenth-century religious reform movement extremist (ghuluww kabìr) and seems to disagree with Wahhābī-inspired plans to demolish tombs such as that of Hawwä̀) he shares with them a focus on sanitary conditions and a desire for religio-moral correction in their refiguration of hajj materiality. ${ }^{91}$ Although, certainly, there are also many differences - for example, in their attitude towards tombs - this observation does seem to reinforce John Willis's conclusion that Ibn Sa'úd's biopolitical and moral governance of Muslims' bodies in Mecca was not exceptionally

$89 \quad$ Things: Religion and the Question of Materiality, ed. Dick Houtman and Birgit Meyer (New York: Fordham University Press, 2012).

9o Cf. Lazarus-Yafeh on the mid-twentieth-century turn from modernism to "neo-orthodoxy" in attitudes concerning the hajj: Lazarus-Yafeh, "Modern Muslim Attitudes towards the Ka'ba and the Hadjdj", 108.

91 al-Batanūnī, al-Rihla al-Hijāzìyya, 146. 
Sa 'ùdī, Wahhābī, or Islamic, but was intricately tied to global developments. ${ }^{92}$ Similarly indicating a broader aspect, for Shahab Ahmed, the ongoing Sa'ùdì destruction of Mecca and Medina's historical structures, emptying it of most references to what he calls the pre-modern Islamic con-text in favour of text only, is "a symptom of the broader condition of the Islamic modern". ${ }^{93}$ al-Batanūnīs many problems with the materiality of the hajj and his according definitive fashioning of the hajj as hygienic, orderly, and rational in his well-read and official travelogue was part of this global history of the Islamic modern, too.

\section{Acknowledgements}

This work is part of the research programme "More Magical than Disneyland': Modern Articulations of Pilgrimage to Mecca" (project no. 36o-25-150), financed by the Dutch Research Council (NwO). I am grateful to project leaders Dr Richard van Leeuwen and Professor Marjo Buitelaar, as well as the project's other team members, Kholoud Al Ajarma and Dr Khadija Kadrouch-Outmany, for providing such an inspiring context to work in. I would also like to thank the journal's two anonymous reviewers for their generous comments, the organisers of the panel on "Ambiguity in Modern Islam" at the Deutsche Orientalistentag in Jena in 2017 for providing a wonderful initial platform for this paper, and, finally, my dear colleagues Justine Bakker and Dr Pieter Coppens for their supportive feedback on final versions of this paper.

92 Willis, "Governing the Living and the Dead", 347.

93 Ahmed, What Is Islam?, 537. 